\title{
KETERAMPILAN MANAJERIAL DAN PENGEMBANGAN KARIR PENGARUHNYA TERHADAP KINERJA KARYAWAN (STUDI PADA KARYAWAN MAINTENANCE PT. GLOBAL MAKARA TEKNIK SITE BRE RANTAU KABUPATEN TAPIN)
}

\author{
Akhmad Jailani Fahmi ${ }^{1}$ \\ Rahmi Widyanti ${ }^{2}$ \\ Maskur $^{3}$ \\ fahmi.akhmadjailani@gmail.com
}

Magister Manajemen,61101,Pascasarjana,Universitas Islam Kalimantan MAB

\begin{abstract}
This research discusses the discussion of theory, discussion of experts, discussion of researchers based on their experience, then developed into a debate - renewal developed - the solution requested to obtain justification (verification) in the form of empirical supporting data in the field.

This study aims to learn more about Managerial Skills and Career Development Influence on Employee Performance (Study on Maintenance Employees of PT. Global Makara Teknik Site BRE Rantau Tapin Regency) in South Kalimantan, The method used in this study is a quantitative method, with as much as 54 assistance, a sample of 54 people and data analysis techniques using the research instrument validity test, reliability test, classic assumptions and using multiple linear regression,

The results of this study indicate that the variable managerial ability individually to the Maintenance Performance of PT. The Makara Global Bara Engineering Site Overseas Temporary Tapin District And Career Development has no significant effect on the Performance of PT. The Global Makara Site of the BRE Rantau Technique in Tapin District, all of the independent variables have a significant influence on the variables that are used together (simultaneous), the adjusted determination (R2) is 0.332 or $33.2 \%$, this shows it is supported by those provided by the variables free of the variables they replace.
\end{abstract}

Keywords: Manajerial Skills, Career Development and Performance

\section{PENDAHULUAN}

Adanya kemampuan profesional manajemen perusahaan, karyawan diharapkan dapat menyusun program kerja yang efektif, menciptakan iklim kerja yang kondusif dan membangun unjuk kerja karyawan serta dapat membimbing karyawanmelaksanakan proses pekerjaan. Di perusahaan, pemimpin senantiasa berinteraksi dengan karyawan 
bawahannya, memonitor dan menilai kegiatan mereka sehari-hari. Rendahnya kinerja karyawan akan berpengaruh terhadap pelaksanaan tugas yang pada gilirannya akan berpengaruh pula terhadap pencapaian tujuan perusahaan (Basuki, 2015). Rendahnya kinerja karyawan harus diidentifikasi penyebabnya. Ada berbagai faktor yang mempengaruhi terhadap kinerja seorang karyawan. Pada kondisi semacam ini, karyawan memegang peranan penting, karena dapat memberikan iklim yang memungkinkan bagi karyawan berkarya dengan penuh semangat. Dengan Keterampilan manajerial yang dimiliki, karyawan membangun dan mempertahankan kinerja karyawan yang positif.

Fenomena yang terjadi selama ini dimana Keterampilan Manajerial seorang pemimpin pada PT. Global Makara Teknik Site BRE Rantau Kabupaten Tapin, dimana dalam bekerja sehari - hari dinilai kurang professional di karenakan banyak pimpinan yang bekerja serta mengambil keputusan tidak berdasarkan saran bawahan dan pimpinan bersikap otoriter sehingga hubungan karyawan dengan atasan tidak terlihat harmonis, selain itu belum adanya pemberian tugas dari atasan yang dibagikan kepada karyawan atau job descripcion dalam bekerja secara pasti selama ini, sehingga karyawan selama ini hanya bekerja sesuai dengan kebiasaan yang mereka kerjakan sehari - hari serta jam kerja yang diberikan kepada karyawan selama ini yang melebihi jam kerja sesuai dengan aturan yang ada.

Penelitian sebelumnya dilakukan Febrio Lengkong, Victor P.K Lengkong, Rita N. Taroreh. 2019. Pengaruh keterampilan, pengalaman dan lingkungan kerja terhadap kinerja karyawan di PT. Tri Mustika Cocominaesa (Minahasa Selatan) Hasil penelitian menunjukkan bahwa Secara parsial Keterampilan Kerja tidak berpengaruh signifikan terhadap Kinerja Karyawan pada PT. Tri Mustika Cocominaesa. Secara parsial Pengalaman berpengaruh signifikan terhadap Kinerja Karyawan pada PT. Tri Mustika Cocominaesa. Secara parsial Lingkungan Kerja berpengaruh signifikan terhadap Kinerja Karyawan pada PT. Tri Mustika Cocominaesa. Secara simultan Keterampilan Kerja, Pengalaman dan Lingkungan Kerja berpengaruh signifikan terhadap Kinerja Karyawan pada PT. Tri Mustika Cocominaesa. Perusahaan sebaiknya mempetahankan karyawan yang memiliki pengalaman paling tinggi yang ada akan meningkatkan Kinerja Karyawan. 
Selain Keterampilan Menajerial yang harus di miliki pimpinan perusahaan, Pengembangan Karir Karyawan juga perlu mendapat perhatian, Pengembangan Sumber Daya Manusia adalah proses persiapan individu-individu untuk memikul tanggung jawab yang berbeda atau lebih tinggi di dalam organisasi, biasanya berkaitan dengan peningkatan kemampuan intelektual untuk melaksanakan pekerjaan yang lebih baik.

Pengembangan karir pada dasarnya sangatlah dibutuhkan bagi perusahaan swasta maupun pemerintahan dikarenakan pengembangan karir berorientasi pada tantangan bisnis di masa yang akan datang dalam menghadapi pesaing. Pengembangan karir memiliki eksistensi dimasa depan yang tergantung pada SDM karena SDM harus lakukan pembinaan karir pada pekerja yang dilaksanakan secara berencana dan berkelanjutan setiap tahunnya. Dengan kata lain pengembangan karir adalah salah satu kegiatan manajemen SDM harus dilaksanakan sebagai kegiatan formal yang dilakukan secara terintegrasi dengan kegiatan SDM lainnya (Widyanti R.,2021) Pengembangan karier memiliki eksistensi yang sangat besar bagi perusahaan swasta maupun pemerintahan dikarenakan pengembangan karir merupakan tolak ukur bagi karyawan di dalam melakukan pembinaan karirnya. Apabila perusahaan swasta ataupun pemerintahan tidak melakukan pengembangan karir maka perusahaan ataupun pemerintahan tidak akan dapat melakukan peningkatan pembinaan karir. Pengembangan karir merupakan rangkaian posisi atau jabatan yang ditempati seseorang selama masa bekerja baik di lingkungan perusahaan swasta maupun di pemerintahan (Widyanti R.,dkk. 2012)

Temuan penelitian ini sejalan dengan penelitian yang dilakukan Temuan penelitian ini sejalan dengan penelitian yang dilakukan oleh Ma'rifah (2010) yang berjudul "Pengaruh Pengembangan Sumber Daya Manusia dan Pelatihan Terhadap Kinerja Karyawan Hotel Pyrenes Yogyakarta", mengemukakan bahwa Pengembangan Sumber Daya Manusia mempengaruhi kinerja karyawan dimana pengaruh Pengembangan Sumber Daya Manusia dan pelatihan terhadap kinerja karyawan adalah positif berpengaruh baik secara parsial maupun simultan. Ini berarti semakin besar Pengembangan Sumber Daya Manusia dan pelatihan maka kinerjanya akan semakin baik.

Selama ini pengembangan karir pada PT. Global Makara Teknik Site BRE Rantau Kabupaten Tapin tidak diberikan perusahaan kepada karyawan, karena 
karyawan PT. Global Makara Teknik Site BRE Rantau Kabupaten Tapin adalah karyawan yang berstatus sebagai karyawan outsourcing. Sistem Outsourcing sendiri diatur dalam pasal 64 sampai dengan pasal 66 Undang - undang No 13 Tahun 2003 tentang Ketenagakerjaan. Pasal 64 yang isinya"Perusahaan dapat menyerahkan sebagian pelaksanaan pekerjaan kepada perusahaan lainnya melalui perjanjian pemborongan pekerjaan atau penyedia jasa pekerja/buruh yang dibuat secara tertulis. Pemborongan pekerjaan sebelumnya telah diatur didalam KUHPerdata didalam Pasal 1601b yang berbunyi "Pemborongan pekerjaan adalah suatu perjanjian dimana pihak yang satu, si pemborong mengikatkan diri untuk menyelenggarakan suatu pekerjaan tertentu bagi pihak yang lain, yaitu pihak yang memborongkan, dengan menerima harga yang telah ditentukan.

Bedasarkan aturan tersebut perjanjian kerja waktu tertentu yang didasarkan atas jangka waktu tertentu dapat diadakan untuk paling lama 2 (dua) tahun dan hanya boleh diperpanjang 1 (satu) kali untuk jangka waktu paling lama 1 (satu) tahun. Kemudian, pengusaha yang bermaksud memperpanjang PKWT tersebut, paling lama 7 (tujuh) hari sebelum PKWT berakhir, pembaruan PKWT hanya dapat diadakan setelah melebihi masa tenggang waktu 30 (tiga puluh) hari berakhirnya PKWT yang lama, pembaharuan perjanjian kerja waktu tertentu ini hanya boleh dilakukan 1 (satu) kali dan paling lama 2 (dua) tahun. Namun faktanya saat ini setelah perjanjian kerja 2 (dua) tahun berkahir bukan pengalihan status karyawan menjadi karyawan menjadi karyawan tetap sesuai aturan ketenaga kerjaan melainkan karyawan akan diistirahatkan atau mengalihkan status karyawan outsourcing tersebut ke perusahaan penyedia jasa tenaga kerja yang lain. Ini guna meminimalisasi kerugian yang dapat dialami perusahaan pemberi kerja dengan merekrut tenaga kerja yang baru.

Temuan penelitian terdahulu yang dilakukan Soffi Rosyidawaty dengan judul Pengaruh Pengembangan Karir Terhadap Kinerja Karyawan Di Telkomsel Regional Jawa Barat Penelitian ini termasuk ke dalam penelitian kuantitatif. menemukan hasil penelitian diketahui bahwa variabel pengembangan karir secara keseluruhan termasuk dalam kategori baik dengan nilai persentase $63.93 \%$. Secara simultan pengembangan karir berpengaruh signifikan terhadap kinerja karyawan, sementara secara parsial menunjukkan pengembangan karir berpengaruh signifikan terhadap kinerja karyawan di regional jawa barat yang memiliki pengaruh sebesar $72.6 \%$. 
Juga penelitian yang dilakukan Tamrin Meda dengan judul penelitian pengaruh kepemimpinan, kemampuan manajerial dan motivasi terhadap kinerja tenaga penjualan pada CV. Gita Mandiri Gowa yang menemukan hasil penelitian (1) Ada pengaruh yang signifikan dan positif antara kepemimpinan kinerja (nilai $\mathrm{T}$ yang dihitung pada 7,784 lebih besar dari t tabel 2,045 dan signifikansi 0,0000); (2) Ada pengaruh yang signifikan dan positif di antara kapasitas manajerial dari kinerja (nilai T hitung sebesar 2.591 lebih besar dari t tabel 2.045 dan signifikansi 0,015); (3) Tidak ada pengaruh motivasi yang signifikan dan positif terhadap kinerja (nilai T yang dihitung pada 0,353 lebih besar dari t tabel 2,045 dan 0,727 signifikansi lebih besar dari 0,05); (4) Ada pengaruh yang signifikan dan positif di antara kepemimpinan, kemampuan manajerial dan motivasi bersama pada kinerja (nilai dihitung pada 104,557 $\mathrm{T}$ lebih besar dari t tabel 3,340 dan 0,000 signifikansi). Faktor-faktor yang paling banyak mempengaruhi kinerja adalah kepemimpinan sedangkan faktor yang tidak berpengaruh adalah motivasi.

Berdasarkan latar belakang masalah yang dikemukakan di atas maka ditetapkan judul penelitian " Keterampilan Manajerial dan Pengembangan karir Karyawan Pengaruhnya Terhadap Kinerja Karyawan pada PT. Global Makara Teknik Site BRE Rantau Kabupaten Tapin”.

\section{TINJAUAN PUSTAKA}

Hall et al (dalam Widyanti R., 2021). mendefinisikan karier sebagai “ ide dalam memilih satu jabatan seperti rata-rata dari suatu kemajuan yang dilalui selama hidup." Demikian juga, secara menyeluruh definisi dari karir diberikan oleh Baruch dan Rosenstein sebagai " satu proses dari pembangunan diri karyawan sepanjang satu alur pengalaman dan pekerjaan pada organisasi." Aryee dan Debrah menyoroti perencanaan karir sebagai suatu taraf aktivitas pekerjaan individu, pengembangan karir adalah suatu tahapan aktivitas pekerjaan dalam organisasi. Sesuai dengan Gutteridge, pengembangan karir menunjuk kepada spesifikasi aktivitas sumber daya manusia untuk mencocokan kesempatan individu dan pekerjaan. Perencanaan Karir adalah sebagai "satu kursus proaktif di pembentukan satu efektif karir yang mungkin dipengaruhi oleh lokus dari kontrol. " Seperti dikutip oleh Aryee dan Debrah, (Widyanti R., 2020) menjelaskan perencanaan karir sebagai “ satu proses sengaja dari menjadi sadar akan diri, kesempatan, batasan, pilihan dan konsekwensi; mengidentifikasi karier 
berhubungan gol; dan pekerjaan program, Pendidikan dan pengalaman pengembangan yang terkait untuk menyediakan arah, pemilihan waktu dan urutan dari tahapan untuk mencapai satu gol karier spesifik". Baruch (2004) dalam Widyanti R., 2021 menyatakan bahwa manajemen karir yang berpengaruh signifikan, terutama pada area manajemen sumber daya manusia (HRM). CPM adalah satu area HRM yang memerlukan upaya khusus dari dua organisasi dan perorangan. Konsep dengan perencanaan karir organisasi didefinisikan oleh Baruch sebagai " satu pendekatan menyeluruh terhadap semuanya aktivitas dan ilmu pengetahuan tentang teknik dimudahkan oleh organisasi yang mana mempunyai kaitan dengan pengembangan karir dari karyawan." Penelitian Kayalar dan Ozmutaf (2009) menemukan pengembangan karir dan perencanaan karir individu meningkatkan kepuasan kerja, sehingga perencanaan karier individu berpengaruh kepada kinerja. Oleh karenanya organisasi harus memperhatikan dan mengelola perencanaan dan pengembangan karier setiap karyawan dengan baik. Hal ini bertujuan agar karyawan mempunyai kemampuan yang lebih tinggi, sehingga lebih dapat mengetahui fungsi dan peranan serta tanggung jawabnya di dalam lingkungan kerja. Melalui perencanaan dan pengembangan karir diharapkan dapat mencapai tingkat kepuasan kerja yang lebih tinggi dan mendapat kejelasan akan jenjangkarir yang akan mereka capai.

\section{METODE PENELITIAN}

Tipe penelitian ini adalah penelitian kuantitatif dengan desain penelitian ini adalah rencana dan sruktur penyelidikan yang disusun sedemikian rupa sehingga peneliti akan memperoleh jawaban untuk pertanyaan - pertanyaan penelitiannya" (Basuki, 2020,2021).

Berdasarkan permasalahan yang diteliti, maka metode dan jenis penelitian ini menggunakan penelitian Ex-Post Facto atau pengukuran sesudah kejadian dan deskriptif korelasional.

Rancangan penelitian menggunakan metode penelitian yang digunakan dalam penelitian ini adalah metode survei. Menurut Umar (2012) bahwa metode survei adalah riset yang diadakan untuk memperoleh faktor-faktor tentang gejala-gejala atas permasalahan yang timbul. Kegiatan penelitian ini dilakukan pada PT. Global Makara Teknik Site BRE Rantau Kabupaten Tapin . 
Menurut Sugiyono, (2006:87) Populasi adalah wilayah generalisasi yang terdiri atas obyek/subyek yang mempunyai kualitas dan karakteristik tertentu yang ditetapkan untuk dipelajari dan kemudian ditarik kesimpulannya. Populasi dalam penelitian ini adalah seluruh karyawanPT. Global Makara Site BRE Rantau Kabupaten Tapin yang berjumlah 248 (dua ratus empat puluh delapan) orang, namun dalam penelitian ini hanya di batasi pada karyawan yang ada pada department maintenance sebanyak 54 (lima puluh empat), semuanya dijadikan responden karena tergolong sampel jenuh (Basuki, 2021).

Menurut Basuki, (2020,2021) skala Likert digunakan untuk mengukur sikap, pendapat, dam persepsi seseorang atau sekelompok orang tentang fenomena sosial. Sehingga untuk mengetahui pengukuran jawaban responden pada penelitian ini yang mana menggunakan instrument penelitian berupa kuesioner, penulis menggunakan metode skala Likert (Likert's Summated Ratings). Kemudian dilakukan uji validitas dan reliabilitas terhadap instrument penelitian. Metode analisis data menggunakan dua metode yaitu; 1) analisis deskriptif, dan 2) analisis inferensial dengan SPSS versi 21.0.

\section{HASIL PENELITIAN DAN PEMBAHASAN}

\section{Uji Validitas}

Item pertanyaan pada variabel independent dan dependent dikatakan valid jika memiliki nilai korelasi lebih besar dari $\mathrm{r}_{\text {syarat }}$, instrument penelitian dapat dikatakan valid apabila koefisien korelasinya $>$ dari 0,3 sugiyono dalam Supriyanto dan Machfudz (2010:296) dapat disimpulkan bahwa semua item pertanyaan adalah valid.

Adapaun hasil uji validitas instrument penelitian dapat dilihat pada tabel 2 dibawah ini:

Tabel 2 Rekapitulasi Hasil Uji Validitas Instrumen Penelitian

\begin{tabular}{|c|l|c|c|}
\hline & Item & $\mathrm{R}$ & Keterangan \\
\hline Variabel & X1.1 & 0,817 & Valid \\
Keterampilan Manajerial & X1.2 & 0,880 & Valid \\
& X1.3 & 0,797 & Valid \\
& X1.4 & 0,871 & Valid \\
& X1.5 & 0,756 & Valid \\
\hline \multirow{3}{*}{ Pengembangan Karir } & X2.1 & 0,780 & Valid \\
(X2) & X2.2 & 0,755 & Valid \\
& X2.3 & 0,768 & Valid \\
& X2.4 & 0,662 & Valid \\
\hline
\end{tabular}




\begin{tabular}{|c|l|l|l|}
\hline & X2.5 & 0,731 & Valid \\
\hline & Y.1 & 0,900 & Valid \\
Kinerja & Y.2 & 0,822 & Valid \\
(Y) & Y.3 & 0,806 & Valid \\
& Y.4 & 0,814 & Valid \\
& Y.5 & 0,821 & Valid \\
\hline
\end{tabular}

Berdasarkan uji validitas pada tabel 2 diatas pada uji validitas semua item pertanyaan kuesioner dinyatakan valid karena semua item pertanyaan memiliki nilai korelasi $>$ dari r syarat 0,3 .

\section{Uji Reliabilitas}

Uji Reliabilitas dilakukan dengan tujuan untuk menguji sejauh mana alat pengukur dapat diandalkan atau dipercaya. Dalam Penelitian ini nilai reliabilitas suatu instrumen diterima jika memiliki Alpha Cronbach minimal 0,6. Arikunto dalam Supriyanto dan Machfudz (2010:296), maka dapat disimpulan bahwa semua item pertanyaan adalah reliabel (dapat diandalkan atau dipercaya).

Adapaun hasil uji reliabilitas instrument penelitian dapat dilihat pada tabel 3 dibawah ini :

Tabel 3 Rekapitulasi Hasil Uji Reliabilitas Instrumen Penelitian

\begin{tabular}{|c|c|c|c|c|}
\hline Variabel & Item & $\begin{array}{l}\text { Cronbach,s Alpha } \\
\text { If Item Deleted }\end{array}$ & $\begin{array}{c}\text { Alpha } \\
\text { Cronbach,s }\end{array}$ & Keterangan \\
\hline $\begin{array}{l}\text { Keterampilan } \\
\text { Manajerial } \\
\text { (X1) }\end{array}$ & $\begin{array}{l}\mathrm{X} 1.1 \\
\mathrm{X} 1.2 \\
\mathrm{X} 1.3 \\
\mathrm{X} 1.4 \\
\mathrm{X} 1.5\end{array}$ & $\begin{array}{l}0,855 \\
0,830 \\
0,859 \\
0,835 \\
0,882\end{array}$ & 0,878 & $\begin{array}{l}\text { Reliabel } \\
\text { Reliabel } \\
\text { Reliabel } \\
\text { Reliabel } \\
\text { Reliabel }\end{array}$ \\
\hline $\begin{array}{c}\text { Pengembangan Karir } \\
\text { (X2) }\end{array}$ & $\begin{array}{l}\mathrm{X} 2.1 \\
\mathrm{X} 2.2 \\
\mathrm{X} 2.3 \\
\mathrm{X} 2.4 \\
\mathrm{X} 2.5 \\
\end{array}$ & $\begin{array}{l}0,729 \\
0,740 \\
0,733 \\
0,796 \\
0,747 \\
\end{array}$ & 0,789 & $\begin{array}{l}\text { Reliabel } \\
\text { Reliabel } \\
\text { Reliabel } \\
\text { Reliabel } \\
\text { Reliabel } \\
\end{array}$ \\
\hline $\begin{array}{l}\text { Kinerja } \\
(\mathrm{Y})\end{array}$ & $\begin{array}{l}\text { Y.1 } \\
\text { Y.2 } \\
\text { Y.3 } \\
\text { Y.4 } \\
\text { Y.5 }\end{array}$ & $\begin{array}{l}0,840 \\
0,869 \\
0,871 \\
0,875 \\
0,867\end{array}$ & 0,889 & $\begin{array}{l}\text { Reliabel } \\
\text { Reliabel } \\
\text { Reliabel } \\
\text { Reliabel } \\
\text { Reliabel }\end{array}$ \\
\hline
\end{tabular}

Berdasarkan hasil uji reliabilitas dalam Penelitian ini nilai reliabilitas semua instrumen diterima atau reliabel karena memiliki Alpha Cronbach minimal dan Cronbach,s Alpha If Item Deleted $>$ dari standar reliabiltas yaitu 0,6 


\section{Analisis Regresi Berganda Variabel Keterampilan Manajerial (X1) dan Pengembangan Karir (X2) terhadap Kinerja (Y).}

Sebagaimana telah dirumuskan sebelumya bahwa dalam penelitian ini sesuai dengan hipotesis :

1. Ada pengaruh ketrampilan manajerial berpengaruh terhadap kinerja karyawan Maintenance PT. Global Makara Teknik Site BRE Rantau Kabupaten Tapin.

2. Ada pengaruh pengembangan karir berpengaruh terhadap kinerja karyawan Maintenance PT. Global Makara Teknik Site BRE Rantau Kabupaten Tapin

3. Ada pengaruh ketrampilan manajerial dan pengembangan karir berpengaruh secara simultan terhadap kinerja karyawan Maintenance PT. Global Makara Teknik Site BRE Rantau Kabupaten Tapin.

4. Variabel yang berpengaruh dominan terhadap kinerja karyawan PT. Global Makara Site BRE Rantau Kabupaten Tapin adalah Pengembangan Karir

Pengujian dilakukan dengan tingkat kepercayaan 95\% atau tingkat signifikansi $0,05(\mathrm{a}=0,05)$. Untuk mengkaji kebenaran hipotesis - hipotesis tersebut digunakan analisis regresi linier berganda. Pada analisis regresi ini akan dilakukan uji serentak atau uji F serta parsial atau uji t.

Tabel 4

Rekapitulasi Analisis Regresi Linier Berganda Pengaruh Keterampilan Manajerial (X1), Pengembangan Karir (X2), Etos Kerja (X3) Dan Etos Kerja (X3) Terhadap Kinerja Karyawan (Y)

\begin{tabular}{|c|c|c|c|c|c|}
\hline Variabel & $\begin{array}{c}\text { Koefisien } \\
\text { Regresi } \\
\text { (bi) }\end{array}$ & t hitung & $t$ tabel & Beta & sig \\
\hline Konstanta & 8,588 & & & & \\
\hline $\begin{array}{l}\text { Keterampilan Manajerial } \\
\text { (X1) }\end{array}$ & 0,626 & 3,388 & 2,009 & 0,618 & 0,001 \\
\hline Pengembangan Karir (X2) & $-0,060$ & $-0,301$ & 2,009 & $-0,055$ & 0,765 \\
\hline \multicolumn{2}{|l|}{ Konstanta $=8,588$} & \multicolumn{4}{|c|}{ F hitung $=12,687$} \\
\hline \multicolumn{2}{|l|}{ Multiple $\mathrm{R}=0,576$} & \multicolumn{4}{|c|}{$\mathrm{F}$ tabel $=3,180$} \\
\hline \multicolumn{2}{|l|}{$\mathrm{R}$ square $\left(\mathrm{R}^{2}\right)=0,332$} & \multicolumn{4}{|c|}{ Sig $=0,000$} \\
\hline
\end{tabular}


Pada tabel 4 dapat dilihat $\mathrm{R}$ Square sebesar 0,332 yang berarti besarnya variasi sumbangan seluruh variabel bebas terhadap variabel terikatnya adalah 33,2\% sedangkan sisanya $66,8 \%$ dijelaskan oleh sebab lain diluar dari penelitian ini.

Nilai R Square sebesar 0,332 atau 33,2\% menyatakan korelasi hubungan variabel bebas Keterampilan Manajerial (X1) dan Pengembangan Karir (X2) Terhadap Kinerja (Y) Karyawan Maintenance PT. Global Makara Teknik Site BRE Rantau Kabupaten Tapin yang kuat.

Berdasarkan tabel 5.8 diperoleh persamaan regresi sebagai berikut:

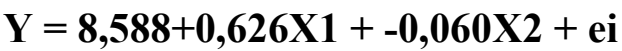

Interpretasi terhadap konstanta $(8,588)$ pengukuan dalam penelitian ini dimana variabel dengan menggunakan skala Likert antara 1 sampai dengan 5 maka tidak boleh diinterpretasikan bahwa jika variabel Keterampilan Manajerial (X1) dan Pengembangan Karir (X2) bernilai nol, karena ketiga variabel tersebut tidak mungkin bernilai nol karena Skala Likert terendah yang digunakan adalah 1 dan berdasarkan hasil perhitungan spss dalam penelitian ini nilai konstanta adalah 8,588 dan termasuk dalam kategori sedang.

Berdasarkan persamaan tersebut, menunjukkan bahwa semua variabel bebas memiliki koefisien regresi positif. Hal ini berarti variabel Keterampilan Manajerial (X1) dan Pengembangan Karir (X2), mempunyai hubungan yang searah atau berbanding lurus dengan variabel terikatnya atau Kinerja (Y). Artinya, jika variabel X1 dan X2 mengalami kenaikan maka variabel terikatnya Y juga ikut mengalami kenaikan, dan jika variabel X1 dan X2 mengalami penurunan, maka variabel terikatnya $\mathrm{Y}$ akan mengalami penurunan.

\section{Uji Hipotesis}

1. Uji Hipotesis I :Ada pengaruh ketrampilan manajerial berpengaruh terhadap kinerja karyawan Maintenance PT. Global Makara Teknik Site BRE Rantau Kabupaten Tapin(Uji t Secara Parsial)

Melalui pengujian ini akan dapat diketahui apakah variabel yang terdiri dari Keterampilan Manajerial (X1) berpengaruh terhadap Kinerja (Y) karyawan Maintenance PT. Global Makara Teknik Site BRE Rantau Kabupaten Tapin, yaitu 
dengan cara membandingkan nilai $\mathrm{t}_{\text {hitung }}$ dengan $\mathrm{t}_{\text {tabel}}$, pada taraf signifikansi (taraf kepercayaan) $5 \%$ dan rumus derajat bebas/degre of freedom, $\mathrm{df}=\mathrm{n}-\mathrm{K}-1=54-$ $3-1=50$ maka didapat nilai $\mathrm{t}_{\text {tabel }} 2,009$. Jika nilai $\mathrm{t}_{\text {hitung }}$ lebih besar dari pada nilai $\mathrm{t}$ tabel maka pengaruhnya signifikan. Selain itu juga dapat dilihat besarnya pengaruh masing-masing variabel bebas terhadap variabel terikatnya.

Pengaruh variabel Keterampilan Manajerial (X1) terhadap Kinerja (Y). Keterampilan Manajerial (X1) berpengaruh signifikan terhadap Kinerja (Y) karena nilai $t_{\text {hitung }}(3,388)>t_{\text {tabel }}(2,009)$, sehingga dapat disimpulkan bahwa Keterampilan Manajerial (X1) berpengaruh siginifikan secara sendiri - sendiri atau parsial terhadap Kinerja (Y)karyawan Maintenance PT. Global Makara Teknik Site BRE Rantau Kabupaten Tapin, dengan demikian hipotesis pertama yang mengatakan Ada pengaruh ketrampilan manajerial berpengaruh terhadap kinerja karyawan Maintenance PT. Global Makara Teknik Site BRE Rantau Kabupaten Tapin adalah benar atau teruji.

2. Uji Hipotesis II : Ada pengaruh pengembangan karir berpengaruh terhadap kinerja karyawan Maintenance PT. Global Makara Teknik Site BRE Rantau Kabupaten Tapin (Uji t Secara Parsial)

Pengaruh variabel Pengembangan Karir (X2) terhadap Kinerja (Y), Pengembangan Karir (X2) tidak berpengaruh signifikan secara parsial terhadap Kinerja (Y). Hal ini dapat dilihat dari tabel 5.8 dimana $t_{\text {hitung }}(-0,301)<t_{\text {tabel }}(2,009)$, sehingga dapat disimpulkan bahwa parsial Pengembangan Karir (X2) tidak berpengaruh siginifikan secara sendiri - sendiri atau parsial terhadap Kinerja (Y)karyawan Maintenance PT. Global Makara Teknik Site BRE Rantau Kabupaten Tapin, dengan demikian hipotesis kedua yang mengatakan Ada pengaruh pengembangan karir berpengaruh terhadap kinerja karyawan Maintenance PT. Global Makara Teknik Site BRE Rantau Kabupaten Tapin adalah salah atau tidak teruji.

3. Uji Hipotesis III: Ada pengaruh keterampilan manajerial dan pengembangan karir berpengaruh secara simultan terhadap kinerja karyawan Maintenance PT. Global Makara Teknik Site BRE Rantau Kabupaten Tapin (Uji F Secara Simultan) 
Uji ini digunakan dengan tujuan untuk membuktikan apakah variabel bebas berpengaruh secara bersama-sama terhadap variabel terikat. Dalam menjawab hipotesis yang telah diajukan pada awal penelitian, menggunakan alat bantu analisis software SPSS versi 21.00. Dari hasil perhitungan melalui SPSS menunjukan $F_{\text {hitung }}$ sebesar 12,687dan $F_{\text {tabel }}$ dengan menggunakan tingkat signifikasi (taraf kepercayaan) $5 \%$ dan rumus derajat bebas/degre of freedom, df $1=\mathrm{K}-1=3-1=$ 2 dan df $2=\mathrm{n}-\mathrm{K}=54-3=51$ maka didapat nilai $\mathrm{F}_{\text {tabel }}$ sebesar 3,180. Ini menyatakan bahwa $F_{\text {hitung }}(12,687)>F_{\text {tabel }}(3,180)$ sehingga hipotesis ketiga yang mengatakan ada pengaruh keterampilan manajerial dan pengembangan karir berpengaruh secara simultan terhadap kinerja karyawan Maintenance PT. Global Makara Teknik Site BRE Rantau Kabupaten Tapin dapat diterima atau teruji.

\section{Kesimpulan}

Berdasarkan hasil analisis dan pembahasan yang telah diuraikan pada bab-bab sebelumnya, maka kesimpulan penelitian ini adalah:

1. Keterampilan Manajerial berpengaruh signifikan terhadap Kinerja Karyawan Maintenance PT. Global Makara Teknik Site BRE Rantau Kabupaten Tapin.

2. Pengembangan Karir tidak berpengaruh signifikan terhadap Kinerja Karyawan Maintenance PT. Global Makara Teknik Site BRE Rantau Kabupaten Tapin.

3. Keterampilan Manajerial dan Pengembangan Karir berpengaruh secara simultan terhadap Kinerja Karyawan Maintenance PT. Global Makara Teknik Site BRE Rantau Kabupaten Tapin.

4. Variabel yang berpengaruh dominan terhadap Kinerja Karyawan Maintenance PT. Global Makara Teknik Site BRE Rantau Kabupaten Tapin adalah Keterampilan Manajerial

\section{DAFTAR PUSTAKA}

Basuki, 2015, Pengaruh Praktik Sumber Daya Manusia Strategik Dan Knowledge Management Terhadap Kinerja Organisasi, Jurnal Komunikasi Bisnis dan Manajemen, Vol.2 No.4 Juli 2015.

Basuki, 2021, Pengantar Metode Penelitian Kuantitatif, Penerbit Media Sains Indonesia, Bandung. 
Fauziah Nami Nasution, Emmy Mariatin, Siti Zahreni. 2018. The Influence of Career Development and Organizational Culture on Employee Performance. International Journal of Scientific Research and Management (IJSRM) ||Volume ||06||Issue||01||Pages||EL-2018-57-65||2018.

Ikechukwu Dialoke (Ph.D) dan Paschal Adighije Jane Nkechi. 2017. Effects of Career Growth on Employees Performance.World Journal of Entrepreneurial Development Studies Vol. 1 No.1, 2017 ISSN 2579-0544 www.iiardpub.org

Irene M. Kakui. Dr. Hazel Gachunga. 2016. Effects Of Career Development On Employee Performance In The Public Sector: A Case Of National Cereals And Produce Board. Vol. 3, Iss. 3 (19), pp 307-324, Aug 17, 2016, www.strategicjournals.com, (CStrategic Journals.

Kwamboka, Florence Obwaya. 2014. The effect of employee career development on performance of Public primary schools in Kenya: a case of Starehe District, Nairobi County. http://ir-library.ku.ac.ke/handle/123456789/6189.

Lantip, Ir..2011. Pengaruh Pelatihan, Pengembangan SDM dan Pemberian Instensif Terhadap Kinerja Karyawan Hotel The 101 Bogor. UNY. Yogyakarta

Ma'rifah .2010. "Pengaruh Pengembangan Sumber Daya Manusia dan Pelatihan Terhadap Kinerja Karyawan Hotel Pyrenes Yogyakarta. UII. Yogyakarta.

Richard C Hofman. 2011. The impact of managerial skills on employee outcomes: a cross cultural study. https://www.researchgate.net. 23(7):1414-1435 - April 2012.

Utami, H. N .2013. Pengaruh Pelatihan dan Pengembangan Sumber Daya Manusia terhadap Kinerja Karyawan Hotel Syahid Surabaya. UMM. Malang.

Widyanti, Rahmi dkk., 2011, The Perception of Individual and Organizational Career in Increasing The Organizational Commitment, Journal of Economis, Business and Accountancy Ventura, Vol. 15 No2. Pp 231-244, STIE Perbanas, Surabaya.

Widyanti, Rahmi, 2019, Manajemen Karir: Teori, Konsep dan Praktik, Penerbit Rizki Artha Mulia, ISBN 978-623-7045-50-2, Makassar.

Widyanti, Rahmi, 2021, Manajemen Karir: Teori, Konsep dan Praktik, Penerbit Media Sains, Bandung.

Widyanti, Rahmi; Basuki; Mursanto; 2021, Meningkatkan Kepuasan Kerja Karyawan Melalui Perencanaan Karir Individu, Al-Kalam Jurnal Komunikasi, Bisnis Dan Manajemen 8 (2), 127-138. 